\title{
Financial Performance Assessment of Non-Life Insurance Companies Traded in Borsa Istanbul via Grey Relational Analysis
}

\author{
Emine Öner Kaya ${ }^{1}$ \\ ${ }^{1}$ Department of Banking, College of Banking and Insurance, Gazi University, Ankara, Turkey \\ Correspondence: Emine Öner Kaya, Department of Banking, College of Banking and Insurance, Gazi University, \\ Ankara 06500, Turkey. Tel: 90-312-216-2116. E-mail: emineoner@gazi.edu.tr
}

Received: February 14, 2016

Accepted: March 3, 2016

Online Published: March 25, 2016

doi:10.5539/ijef.v8n4p277

URL: http://dx.doi.org/10.5539/ijef.v8n4p277

\begin{abstract}
The analysis of the financial performances of non-life insurance companies traded in Borsa Istanbul (BIST) as of the end of 2014 via the grey relational analysis (GRA) method has been aimed in this study. Financial performances of non-life insurance companies in the 2010 to 2014 period have been examined in terms of the capital adequacy ratios, liquidity ratios, operating ratios, and profitability ratios. The results of the GRA based on 16 financial ratios indicate that Aksigorta has been ranked first and Unico Sigorta has been ranked last in terms of financial performance for the 2010 to 2014 period. The results also show that profitability ratios have the greatest impact on the financial performance of non-life insurance companies traded in BIST.
\end{abstract}

Keywords: non-life insurance companies, grey relational analysis, financial performance, financial ratios, Borsa Istanbul.

\section{Introduction}

Financial performance is critical on the survival and continuous growth of insurance companies (Kung, Yan, \& Chuang, 2006). Moreover, financial performances of insurance companies have direct implications on a wide section of the public from policyholders to shareholders, from company employees to intermediaries, and from regulatory authorities to potential investors. Therefore, the measurement and assessment of the financial performances of insurance companies are of utmost importance. The results of the literature review showed that the measurement of financial performance using grey relational analysis (GRA) has been studied for the insurance companies in Turkey. However, the difference of this study is that it has included the financial ratios specific to the insurance industry (solvency ratio, premium retention ratio, loss ratio, etc.) in the analysis. Furthermore, the weights used in the analysis for each financial ratio are determined based on the views of 15 senior managers (especially managers responsible for the financial affairs) working in the non-life insurance companies in Turkey. The aim of this study is to investigate the financial performances of non-life insurance companies traded in BIST via the GRA method. In this framework, the rest of the study is organized as follows. The second section presents the characteristics of the Turkish insurance industry. The third section analyzes the relevant previous studies measuring the financial performance of insurance companies via the GRA method. The fourth section describes the research design, including the data sources, the variables used in the analysis, and the implementation of the GRA method. The fifth section demonstrates the empirical analysis. The final section presents the conclusion.

\section{Insurance Industry in Turkey}

Total direct premiums written in the global insurance industry have reached USD 4778 billion as of the end of 2014. In the global insurance industry, the share of life insurance premiums was realized at 56\%, and the share of non-life premiums was realized at $44 \%$. In other words, total direct premiums written were USD 2655 billion in the life sector, and USD 2124 billion in the non-life insurance sector. Turkey, with a share of $0.24 \%$, was ranked 39 th in the world direct premium volume in 2014 (27th in non-life premium volume and 47th in life premium volume). By the end of 2014, total direct premiums written in the Turkish insurance industry amounted to USD 11.6 billion, the USD 10.1 billion of which was produced in non-life and USD 1.5 billion in life insurance branches (Swiss Re, 2015). In contrast to the global insurance industry, it is possible to say that the non-life insurance sector is dominant in the Turkish insurance industry. The premium volume of life and non-life insurance in the world and Turkey for the 2010 to 2014 period is shown in Figure 1. 


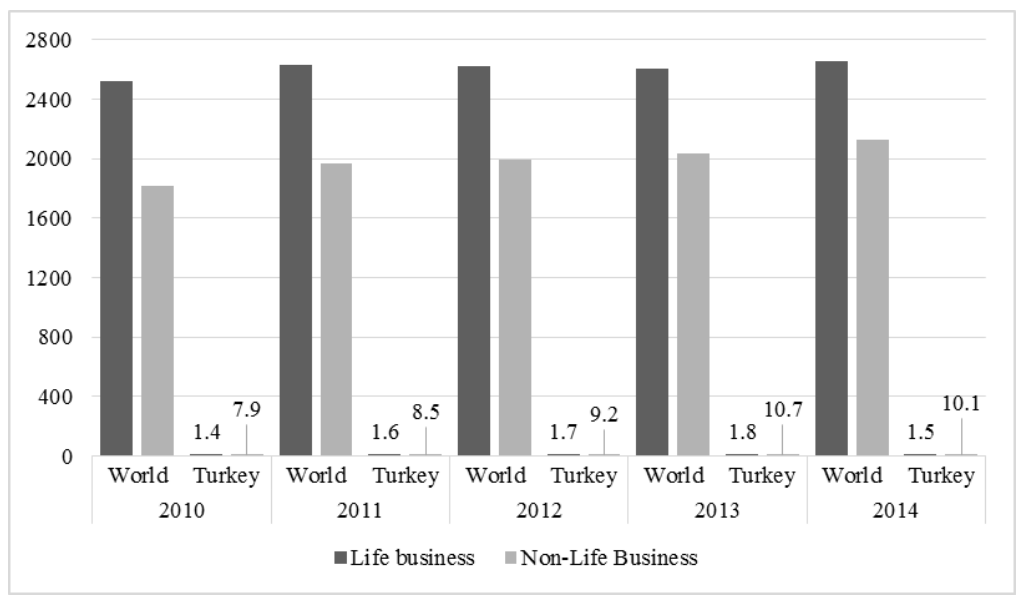

Figure 1. Premium volume in the world and Turkey (in billions of USD)

Source: Own graphics based on the data of Sigma Magazines by Swiss Re.

Insurance penetration, which is also known as premiums in \% of gross domestic product (GDP), and insurance density, which is also known as premiums per capita, could be used for assessing the level of development of the Turkish insurance industry. Accordingly, Figure 2 shows premiums in \% of GDP and premiums per capita for the 2010 to 2014 period for the global insurance industry and Turkish insurance industry.

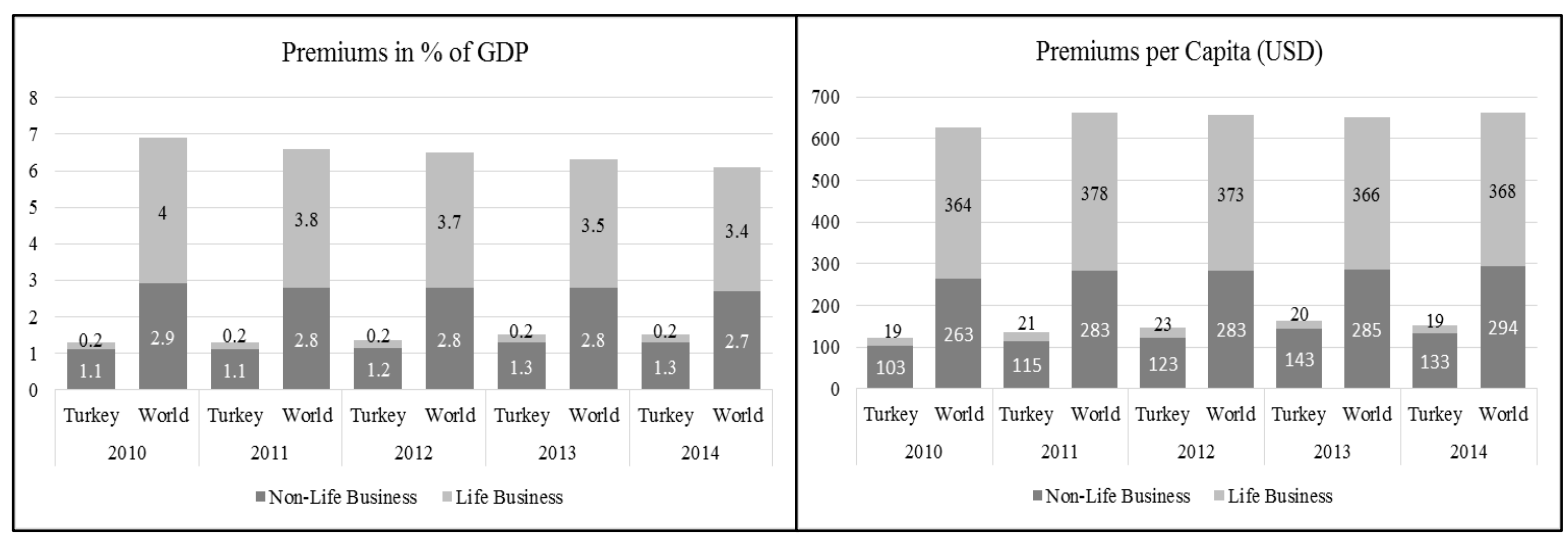

Figure 1. Insurance penetration and insurance density between years 2010 and 2014

Source: Own graphics based on the data of Sigma Magazines by Swiss Re.

Premiums in $\%$ of GDP were $6.1 \%$ in the world, and $1.5 \%$ in Turkey, and premiums per capita was USD 662 in the world, and USD 152 in Turkey as of the end of 2014 (Swiss Re, 2015). The analysis of the premium volume, premiums in \% of GDP, and premiums per capita for the 2010 to 2014 period shows that the Turkish insurance industry has a small share in the global insurance industry. Therefore, it is possible to say that the Turkish insurance industry can utilize a small fraction of its potential yet, and it is still under development.

As of 2014 year-end, 38 non-life insurance, 5 life insurance, and 19 pension companies actively operate in the Turkish insurance industry. In addition, there is also one active reinsurance company. In total, the number of insurance, reinsurance, and pension companies has reached 63 by the end of 2014 (the Undersecretariat of Treasury, 2014). Due to the low penetration rate and high growth potential, foreign investors have shown great interest in the Turkish insurance market. By the end of 2014, 26 of 38 non-life insurance companies and 18 of 24 life and pension companies have international capital directly or indirectly in Turkey. In addition, the share of international capital is 50\% or above in 39 of these companies. Furthermore, by the end of 2014, the share of international capital reached $64.29 \%$ of premium volume and $71.66 \%$ of total paid-in capital (the Undersecretariat of Treasury, 2014). Figure 3 shows the international partners' share in premium volume and total paid in capital in the Turkish insurance market between years 2010 and 2014. 


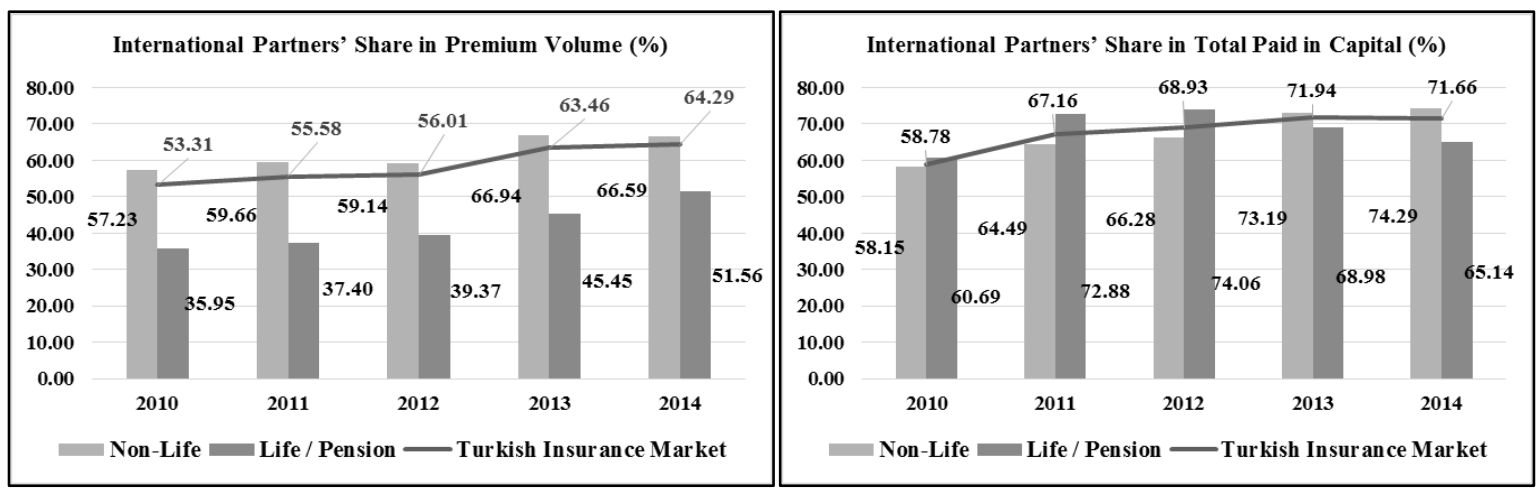

Figure 2. International partners' share in premium volume and total paid in capital in Turkish insurance market for the 2010 to 2014 period

Source: Own graphics based on the Undersecretariat of Treasury's Annual Reports about Insurance and Private Pension Activities - 2014.

The insurance industry is considered as one of the most important institutional savings and investment actors in the financial system, and the share of the insurance industry in the financial system in Turkey is quite low compared to developed countries in terms of total assets. Table 1 shows the share of the sub-sectors in total assets of the Turkish finance sector for the 2010 to 2014 period.

Table 1. Share of the subsectors in total assets of the Turkish finance sector

\begin{tabular}{lccccc}
\hline & 2010 & 2011 & 2012 & 2013 & 2014 \\
\hline Banks & 88.47 & 89.93 & 89.46 & 89.88 & 89.57 \\
Insurance, Reins., and Pension Comp. & $\mathbf{3 . 2 4}$ & $\mathbf{3 . 1 4}$ & $\mathbf{3 . 4 3}$ & $\mathbf{3 . 3 4}$ & $\mathbf{3 . 6 4}$ \\
Securities Mutual Funds & 2.92 & 2.23 & 2.00 & 1.58 & 1.50 \\
Leasing Companies & 1.38 & 1.37 & 1.33 & 1.48 & 1.46 \\
Factoring Companies & 1.28 & 1.16 & 1.19 & 1.13 & 1.19 \\
Real Estate Investment Ass. & 1.51 & 0.86 & 1.03 & 0.97 & 0.99 \\
Consumer Finance Companies & 0.53 & 0.66 & 0.76 & 0.83 & 0.91 \\
Securities Intermediary Inst. & 0.66 & 0.59 & 0.74 & 0.73 & 0.68 \\
Enterprise Capital Management Comp. & 0.02 & 0.05 & 0.05 & 0.06 & 0.07 \\
\hline
\end{tabular}

Source: Own graphics based on the Undersecretariat of Treasury's Annual Reports about Insurance and Private Pension Activities - 2014.

The total assets of the Turkish financial sector (excluding BIST) increased by approximately $15.5 \%$ in 2014 to approximately USD 1 trillion (the Undersecretariat of Treasury, 2014). The analysis of the total assets of the Turkish financial sector for the 2010 to 2014 period shows that insurance, reinsurance, and pension companies have the second largest share in the Turkish financial sector. On the contrary, the banking sector traditionally is the largest sector among Turkey's financial sectors by its asset size. However, the banking sector's total assets increased by $15.1 \%$ in 2014, whereas total assets of insurance, reinsurance, and pension companies experienced an approximately $26 \%$ growth due to the $43.7 \%$ increase in individual pension funds (the Undersecretariat of Treasury, 2014). Consequently, the share of insurance, reinsurance, and pension companies in the financial system increased to $3.64 \%$ in 2014 and $3.34 \%$ in 2013.

\section{Literature Review}

Traditional statistical methods used to measure the performance of companies often require a large number of data with assumptions of normal distribution (Kung et al., 2006; Yan \& Kung, 2011). The grey system theory, which was initiated by Deng (1982), can be used in cases where a limited amount of data and the data are not normally distributed (Kung \& Cheng, 2004; Wen, 2004; Kung et al., 2006). In the grey system theory, the level of knowledge is indicated by colors. "Black" represents the unknown information, "white" represents the completely known information, and "grey" represents the information that is partially known and partially unknown (Liu \& Lin, 2006). In other words, "grey" means poor, incomplete, uncertain, etc. (Deng, 1989). GRA is useful for determining the importance of factors for a system with a limited amount of data (Chu, Hsu, \& Lai, 2008) and it is especially suitable for the evaluation of the financial performance of companies (Kung \& Wen, 2007). Accordingly, in recent years, the GRA method has been often used to measure the performance of 
companies operating in various industries (Kung \& Wen, 2007; Wu, Hsiao, \& Tsai, 2008; Wu, Lin, \& Tsai, 2010; Lin \& Chang, 2010; Huang \& Peng, 2011, etc.). At the same time, the GRA method has also been used to evaluate the performance of insurance companies in recent years.

In studies where the performance of insurance companies was measured via the GRA method, the financial ratios were often used. Kung et al. (2006) have analyzed the performance of 16 non-life insurance companies in Taiwan during the 2000 to 2004 period. They have chosen 24 financial ratios to be the performance evaluation variables of non-life insurance companies and divided these ratios into five performance indicators, including profitability, capital operational capability, capital structure, solvency, and management efficiency. The results of GRA have revealed that return on assets (ROA) ratio, funds utilization efficiency ratio, current debt to capital ratio, equity ratio, and net operating profit to retention premium ratio have the greatest impact on the performance of non-life insurance companies. By combining the Analytic Hierarchy Process (AHP) and GRA, Tsai, Huang, and Wang (2008) have proposed a performance evaluation model for the property-liability insurance companies. They have used 3 main evaluation criteria (including business index, profit ability index, and whole company operating index) and 11 sub-evaluation criteria in the analysis and ranked 14 Taiwanese property-liability insurance companies based on the results of the analysis. By applying GRA, Yan and Kung (2011) have also ranked the business performance of 15 larger-scale Taiwanese insurance companies based on the grey relational grade for the 2004 to 2008 period. Twenty-four financial ratios have been selected for this study and these ratios have been separated into five categories. These categories are capital structure, profitability, debt-paying ability, business performance, and capital employment. Consequently, the results of these and other studies have indicated that the GRA method is convenient for the performance evaluation of insurance companies.

In the Turkish insurance industry, Peker and Baki (2011), Elitaş, Eleren, Yıldız, and Doğan (2012), and Kula, Kandemir, and Baykut (2015) have analyzed the performance of insurance companies by the GRA method. Peker and Baki (2011) and Elitaş et al. (2012) have used 10 financial ratios and divided these ratios into three performance indicators (liquidity, financial leverage, and profitability). They have used current ratio and acid test ratio as liquidity indicators; debt to equity ratio, debt to total assets ratio, short-term debt to total debt ratio, and total assets to equity ratio as financial leverage indicators; and gross profit margin, net profit margin, ROA, and return on equity (ROE) as profitability indicators. Peker and Baki (2011) have ranked the financial performance of three leading insurance companies operating in Turkey based on the data of 2008. With GRA, they have found that an insurance company that has high liquidity ratios may have high performance. Elitaş et al. (2012) have investigated the financial performances of seven insurance companies traded in ISE for the 2010 to 2011 period and found that the most important ratios in the financial success of insurance companies are the liquidity ratios. In a similar manner, Kula et al. (2015) have used 10 financial indicators (current ratio, net profit margin, earnings per share, equity to total assets ratio, ROE, ROA, market value, total assets, short-term debt to total debt ratio, and debt to total assets ratio) to determine the financial performance of eight insurance companies traded in BIST using the data of the end of 2013. The findings of the study indicate that the financial performance of an insurance company can be increased by increasing equity in the capital structure, maintaining the high level of liquidity and improving the profitability.

\section{Research Design}

The data sources, the variables used in the analysis, and the methodology are explained in this section of the study.

\subsection{Data Sources and Variables}

This study analyzes the financial performances of non-life insurance companies traded in BIST as of the end of 2014 via the GRA method. By the end of 2014, only 6 of the 38 non-life insurance companies are traded in BIST. Accordingly, the list of the companies included in the analysis is presented in Table 2.

Table 2. List of the non-life insurance companies included in the analysis

\begin{tabular}{cc}
\hline Insurance Companies & Code \\
\hline Aksigorta & C1 \\
Anadolu Sigorta & C2 \\
Güneş Sigorta & C3 \\
Halk Sigorta & C4 \\
Ray Sigorta & C5 \\
Unico Sigorta & C6 \\
\hline
\end{tabular}


The study covers a period of 5 years between 2010 and 2014. Financial performances of non-life insurance companies in the 2010 to 2014 period have been examined in terms of the capital adequacy ratios, liquidity ratios, operating ratios, and profitability ratios. The financial ratios used in the analysis are presented in Table 3.

Table 3. Financial ratios

\begin{tabular}{|c|c|c|c|}
\hline & Ratio & Code & Target \\
\hline \multirow{5}{*}{$\begin{array}{c}\text { Capital Adequacy } \\
\text { Ratios }\end{array}$} & Solvency Ratio* & CAR1 & Larger the better \\
\hline & Gross Written Premiums / Equity Capital & CAR2 & Smaller the better \\
\hline & Net Written Premiums / Equity Capital & CAR3 & Smaller the better \\
\hline & Equity Capital / Total Assets & CAR4 & Larger the better \\
\hline & Equity Capital / Net Technical Reserves & CAR5 & Larger the better \\
\hline \multirow{3}{*}{ Liquidity Ratios } & Current Ratio & LR1 & Larger the better \\
\hline & Liquidity Ratio & LR2 & Larger the better \\
\hline & Liquid Assets / Total Assets & LR3 & Larger the better \\
\hline \multirow{3}{*}{ Operating Ratios } & Premium Retention Ratio & OR1 & Larger the better \\
\hline & Paid Loss Ratio & OR2 & Larger the better \\
\hline & Motor Insurance & OR3 & Smaller the better \\
\hline \multirow{5}{*}{ Profitability Ratios } & Loss Ratio & PR1 & Smaller the better \\
\hline & Technical Profitability Ratio & PR2 & Larger the better \\
\hline & Sales Profitability Ratio & PR3 & Larger the better \\
\hline & Return on Assets (ROA) & PR4 & Larger the better \\
\hline & Return on Equity (ROE) & PR5 & Larger the better \\
\hline
\end{tabular}

* calculated based on solvency requirement method in Turkey.

The financial ratios were calculated using the annual data of the companies. These data were obtained from the annual reports of the companies. All financial ratios used in the analysis were selected taking into account the availability of data and based on the Undersecretariat of Treasury's Annual Reports about Insurance and Private Pension Activities. Explanations related to these ratios are detailed below.

\section{1) Capital Adequacy Ratios}

To have the financial strength to fulfill their obligations to policyholders is very important for insurance companies. The amount of equity capital is an important indicator to measure the financial strength of an insurance company. "Solvency ratio" is one of the most important measure assessing the capital adequacy of insurance companies in terms of quality and quantity. This ratio is calculated by dividing available equity capital by required equity capital. In accordance with the relevant legislation (Note 1), available equity capital should not be less than the required equity capital. Therefore, solvency ratio should be greater than 1 (or 100\%). The "ratios of gross written premiums to equity capital" and "net written premiums to equity capital" show the insurance company's exposure to underwriting risk. Higher values of these ratios increase the company's vulnerability to underwriting risk. Therefore, insurance companies should also increase their equity capital due to the increase in premium production. During assessment of capital adequacy of insurance companies, attention should be paid to the ratio of equity capital to total assets and technical reserves. The "ratio of equity capital to total assets" indicates how much equity capital is being used in the financing of the assets. This ratio varies considerably across insurance companies depending on product mix, assets, and reinsurance (Harrington \& Niehaus, 2004). However, the high ratio of equity capital to total assets can be interpreted as a strong financial structure. Another ratio used in this study in relation to capital adequacy is the "ratio of equity capital to net technical reserves". This ratio shows the power of equity capital to meet the technical reserves. If this ratio is high, it is an important indicator of the company's financial strength. Consequently, in case of an increase in total assets and technical reserves, to maintain the existing ratio, insurance companies should increase their equity capital.

\section{2) Liquidity Ratios}

Liquidity ratios show the relationship of a company's cash and other current assets to its current liabilities (Brigham \& Houston, 2001). A number of ratios can be used to measure the liquidity of non-life insurance companies. "Current ratio", which is one of the frequently used liquidity ratios, is equal to current assets divided by current liabilities. The second important liquidity measure is the "liquidity ratio". In this study, liquidity ratio 
is calculated by dividing liquid assets (include cash and cash equivalents and financial assets) by current liabilities. Another liquidity measure is the "ratio of liquid assets to total assets", and this ratio indicates the weight of liquid assets within the total assets. Because non-life insurance contracts are generally short-term and non-life claims' payments can vary considerably, liquidity is of particular importance to non-life insurance companies (Shiu, 2004). Accordingly, liquidity ratios are desired to be high by insurers. However, this situation does not mean that all the funds should be invested in liquid assets by the non-life insurance companies (Shiu, 2004). It is important to strike a balance between the profitability and the liquidity risk exposure of the company (Öner Kaya, 2015).

\section{3) Operating Ratios}

Three ratios were used in this study as the operating measure of non-life insurance companies. These are premium retention ratio, paid loss ratio, and the share of motor insurance in the company's portfolio. "Premium retention ratio" indicates the amount of risk an insurance company retains rather than transfers to reinsurers. This ratio is calculated by dividing net written premiums by gross written premiums. Insurers desire a high premium retention ratio with a low loss ratio. "Paid loss ratio", which refers to the quickness of claims payment (Tiryaki, 2013), is calculated by dividing gross claims paid by total of gross claims paid and gross provision for outstanding claims in this study. This ratio is expected to be in the $60 \%$ and $80 \%$ range (Başpınar, 2005). The "share of motor insurance (including land vehicle and land vehicle liability branches) in the company's portfolio" is calculated by dividing gross written premiums in motor insurance by total gross written premiums of the company. Because the competition is intense in motor insurance and insurance companies find it difficult to gain profit from this portfolio (Özer, 2010), the decrease in the share of motor insurance in the company's portfolio, with simultaneous increase in the share of other insurance branches (Kozak, 2011), is preferred by insurers.

\section{4) Profitability Ratios}

A number of ratios can be used to measure the profitability of non-life insurance companies. "Loss ratio" is one of the most important underwriting profitability measures for non-life insurance companies. This ratio demonstrates the effectiveness of the underwriting activities of the companies (Öner Kaya, 2015). Loss ratio is calculated by dividing incurred losses by earned premiums (Dorfman, 2005). There is a reverse relationship between loss ratio and financial performance. Consequently, a low loss ratio is preferred by insurers. Loss ratio is generally in the $65 \%$ to $75 \%$ range (Rejda \& McNamara, 2014). Another important underwriting profitability measure is technical profitability ratio. "Technical profitability ratio" assesses the effectiveness of the core insurance activities of the insurance company (Kozak, 2011), and is calculated by dividing technical profit by gross written premiums. "Sales profitability ratio" also measure profitability compared to gross written premiums. This ratio associates net income before taxes with gross written premiums, and is calculated by dividing net income before taxes to gross written premiums (Öner Kaya, 2015). The high ratios regarding technical profitability and sales profitability are desired by insurers. In addition to these ratios, to measure the profitability, net income before taxes could be compared to total assets or equity capital. The ratio of net income before taxes to total assets measures the ROA, and indicates the ability of the company's assets to generate net income before the influence of taxes. Another ratio of profitability focuses on the ROE, and it is calculated by dividing net income before taxes to equity capital. These are the most common measures of profitability, and an insurer naturally prefers a high ROA and a high ROE.

\subsection{Methodology}

This study has used the grey relational analysis (GRA) method to analyze the financial performance of non-life insurance companies in Turkey. Based on $\mathrm{Wu}$ and Chen's (1999) calculation of grey relational grades, application steps of the GRA method can be described as follows (Wu, 2002; Zhai, Khoo, \& Zhong, 2009):

\section{Step 1. Construction of the decision matrix}

Assuming that there are $\mathrm{n}$ data sequences (non-life insurance companies in this study) characterized by $\mathrm{m}$ criteria (16 financial ratios are selected for this study), the compared sequences can be shown in a matrix form:

$$
X=\left[\begin{array}{cccc}
x_{1}(1) & x_{1}(2) & \cdots & x_{1}(m) \\
x_{2}(1) & x_{2}(2) & \cdots & x_{2}(m) \\
\vdots & \vdots & \ddots & \vdots \\
x_{n}(1) & x_{n}(2) & \cdots & x_{n}(m)
\end{array}\right]
$$

where $x_{i}(j)$ is the value of the $i$ th insurance company corresponding to the $j$ th financial ratio $(i=1, \ldots, n ; j=$ $1, \ldots, m)$. 


\section{Step 2. Normalization of the data set}

To obtain the comparable scales, the data set is normalized (Feng \& Wang, 2000). The data can be normalized by one of the three regimes: larger the better, smaller the better, and nominal the best.

For larger is the better normalization, the formula to transform $x_{i}(j)$ to $x_{i}^{*}(j)$ is defined as:

$$
x_{i}^{*}(j)=\frac{x_{i}(j)-\min _{i=1}^{n}\left[x_{i}(j)\right]}{\max _{i=1}^{n}\left[x_{i}(j)\right]-\min _{i=1}^{n}\left[x_{i}(j)\right]}
$$

where $\min _{i=1}^{n}\left[x_{i}(j)\right]$ is the minimum value of the $j$ th financial ratio and $\max _{i=1}^{n}\left[x_{i}(j)\right]$ is the maximum value of the $j$ th financial ratio.

For smaller is the better normalization, the formula as follows:

$$
x_{i}^{*}(j)=\frac{\max _{i=1}^{n}\left[x_{i}(j)\right]-x_{i}(j)}{\max _{i=1}^{n}\left[x_{i}(j)\right]-\min _{i=1}^{n}\left[x_{i}(j)\right]}
$$

For nominal is the best normalization, the formula is defined as:

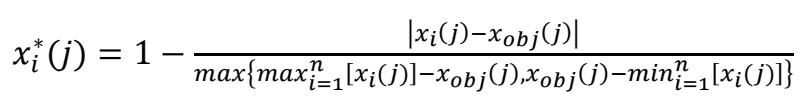

where $x_{o b j}(j)$ is the target (ideal) value of the $j$ th financial ratio, and

$$
\underset{i=1}{n} \underset{i=1}{n}\left[x_{i}(j)\right] \leq x_{o b j}(j) \leq \max _{i=1}\left[x_{i}(j)\right]
$$

Step 3. Construction of the normalized matrix and generation of the reference sequence

After the normalization process, Equation (5) shows the normalized matrix, which is the revised version of the initial decision matrix, and Equation (6) shows the reference sequence.

$$
\begin{aligned}
X^{*} & =\left[\begin{array}{cccc}
x_{1}^{*}(1) & x_{1}^{*}(2) & \ldots & x_{1}^{*}(m) \\
x_{2}^{*}(1) & x_{2}^{*}(2) & \ldots & x_{2}^{*}(m) \\
\vdots & \vdots & \ddots & \vdots \\
x_{n}^{*}(1) & x_{n}^{*}(2) & \cdots & x_{n}^{*}(m)
\end{array}\right] \\
x_{0}^{*} & =x_{0}^{*}(1), x_{0}^{*}(2), \ldots, x_{0}^{*}(j), \ldots, x_{0}^{*}(n)
\end{aligned}
$$

where $x_{0}^{*}(j)$ is the reference value for the $j$ th financial ratio and is determined by Equation (7).

$$
x_{0}^{*}(j)=\max _{i=1}^{n}\left[x_{i}^{*}(j)\right]
$$

Step 4. Construction of the difference matrix

$\Delta_{0 i}(j)$ is the absolute value of difference between the normalized value and the reference value of the $j$ th financial ratio and is calculated by Equation (8).

$$
\Delta_{0 i}(j)=\left|x_{0}^{*}(j)-x_{i}^{*}(j)\right|
$$

After the calculation of $\Delta_{0 i}(j)$ values, the constructed difference matrix is shown in Equation (9).

Step 5. Calculation of the grey relational coefficient

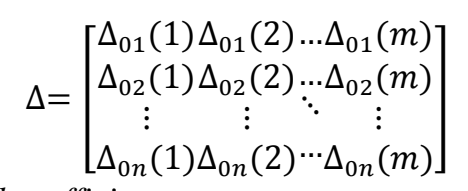

The grey relational coefficient is calculated using the Equation (10).

$$
\gamma_{0 i}(j)=\frac{\min _{i=1}^{n} \min _{j=1}^{m} \Delta_{0 i}(j)+\zeta \times \max _{i=1}^{n} \max _{j=1}^{m} \Delta_{0 i}(j)}{\Delta_{0 i}(j)+\zeta \times \max _{i=1}^{n} \max _{j=1}^{m} \Delta_{0 i}(j)}
$$

where $\gamma_{0 i}(j)$ is the grey relational coefficient of the $j$ th financial ratio and $\zeta$ is the distinguishing coefficient. This coefficient is a value between 0 and 1 . However, $\zeta$ usually ranges between 0.1 and 0.5 and reduces the effect of extremely large $\max _{i=1}^{n} \max _{j=1}^{m} \Delta_{0 i}(j)$ in cases where data variation is large (Chang \& Lin, 1999).

Step 6. Calculation of the grey relational grades

If weights of the financial ratios are determined, the grey relational grade is calculated as follows: 


$$
\Gamma_{0 i}=\sum_{j=1}^{m}\left[w(j) \times \gamma_{0 i}(j)\right], \quad \sum_{j=1}^{m} w(j)=1
$$

where $\Gamma_{0 i}$ is the grey relational grade, and $w(j)$ is the weight of the $j$ th financial ratio in this study.

Consequently, the performance of insurance companies can be ranked according to the grey relational grades. The higher grey relational grade shows better financial performance.

\section{Empirical Analysis}

Within the scope of the study primarily the financial ratios were calculated for each of the six non-life insurance companies for the 2010 to 2014 period. Then, 5-year averages of the financial ratios for each company were taken. Table 4 presents the decision matrix showing the 5-year average values of 16 financial ratios for 6 non-life insurance companies traded in BIST.

Table 4. Decision matrix

\begin{tabular}{|c|c|c|c|c|c|c|c|c|}
\hline & CAR1 & CAR2 & CAR3 & CAR4 & CAR5 & LR1 & LR2 & LR3 \\
\hline $\mathrm{C} 1$ & 1.58 & 2.91 & 2.12 & 0.34 & 0.64 & 1.48 & 0.96 & 0.61 \\
\hline $\mathrm{C} 2$ & 1.38 & 2.66 & 2.05 & 0.32 & 0.59 & 1.33 & 0.85 & 0.56 \\
\hline $\mathrm{C} 3$ & 1.14 & 3.03 & 1.62 & 0.30 & 0.63 & 0.94 & 0.35 & 0.23 \\
\hline $\mathrm{C} 4$ & 1.09 & 3.51 & 2.32 & 0.27 & 0.50 & 1.36 & 1.01 & 0.71 \\
\hline $\mathrm{C} 5$ & 1.05 & 3.65 & 1.89 & 0.26 & 0.49 & 1.26 & 0.68 & 0.48 \\
\hline \multirow[t]{2}{*}{ C6 } & 0.99 & 8.53 & 6.61 & 0.14 & 0.19 & 1.18 & 0.85 & 0.68 \\
\hline & OR1 & OR2 & OR3 & PR1 & PR2 & PR3 & PR4 & PR5 \\
\hline $\mathrm{C} 1$ & 0.73 & 0.66 & 0.49 & 0.70 & 0.04 & 0.05 & 0.05 & 0.14 \\
\hline $\mathrm{C} 2$ & 0.77 & 0.65 & 0.54 & 0.77 & 0.01 & 0.01 & 0.01 & 0.03 \\
\hline $\mathrm{C} 3$ & 0.53 & 0.61 & 0.43 & 0.80 & 0.00 & -0.01 & -0.01 & -0.04 \\
\hline $\mathrm{C} 4$ & 0.66 & 0.56 & 0.52 & 0.72 & 0.03 & 0.05 & 0.05 & 0.14 \\
\hline C5 & 0.52 & 0.48 & 0.43 & 0.71 & 0.00 & -0.01 & -0.01 & -0.08 \\
\hline C6 & 0.79 & 0.44 & 0.57 & 0.95 & -0.23 & -0.20 & -0.11 & -3.54 \\
\hline
\end{tabular}

Normalized values of the financial ratios and the reference sequence are presented in Table 5. In the normalization process, Equation (2) was used for the financial ratios, which have the expectancy of "larger the better" (CAR1, CAR4, CAR5, LR1, LR2, LR3, OR1, OR2, PR2, PR3, PR4, and PR5), and Equation (3) was used for the financial ratios, which have the expectancy of "smaller the better" (CAR2, CAR3, OR3, and PR1). The reference sequence was determined by selecting the largest normalized value of each financial ratio.

Table 5. Normalized matrix and reference sequence

\begin{tabular}{ccccccccc}
\hline & CAR1 & CAR2 & CAR3 & CAR4 & CAR5 & LR1 & LR2 & LR3 \\
\hline Reference & 1.00 & 1.00 & 1.00 & 1.00 & 1.00 & 1.00 & 1.00 & 1.00 \\
C1 & 1.00 & 0.96 & 0.90 & 1.00 & 1.00 & 1.00 & 0.92 & 0.80 \\
C2 & 0.66 & 1.00 & 0.91 & 0.93 & 0.90 & 0.72 & 0.77 & 0.68 \\
C3 & 0.26 & 0.94 & 1.00 & 0.83 & 0.97 & 0.00 & 0.00 & 0.00 \\
C4 & 0.18 & 0.86 & 0.86 & 0.68 & 0.69 & 0.79 & 1.00 & 1.00 \\
C5 & 0.10 & 0.83 & 0.95 & 0.60 & 0.68 & 0.60 & 0.51 & 0.52 \\
C6 & 0.00 & 0.00 & 0.00 & 0.00 & 0.00 & 0.45 & 0.76 & 0.93 \\
\hline & OR1 & OR2 & OR3 & PR1 & PR2 & PR3 & PR4 & PR5 \\
\hline Reference & 1.00 & 1.00 & 1.00 & 1.00 & 1.00 & 1.00 & 1.00 & 1.00 \\
C1 & 0.77 & 1.00 & 0.58 & 1.00 & 1.00 & 0.99 & 1.00 & 1.00 \\
C2 & 0.93 & 0.94 & 0.19 & 0.73 & 0.91 & 0.85 & 0.76 & 0.97 \\
C3 & 0.07 & 0.75 & 1.00 & 0.61 & 0.87 & 0.74 & 0.62 & 0.95 \\
C4 & 0.51 & 0.51 & 0.33 & 0.91 & 0.96 & 1.00 & 0.99 & 1.00 \\
C5 & 0.00 & 0.15 & 0.95 & 0.94 & 0.87 & 0.75 & 0.61 & 0.94 \\
C6 & 1.00 & 0.00 & 0.00 & 0.00 & 0.00 & 0.00 & 0.00 & 0.00 \\
\hline
\end{tabular}

After the normalization process, Table 6 provides the difference matrix that was generated using Equation (8). 
Table 6. Difference matrix

\begin{tabular}{|c|c|c|c|c|c|c|c|c|}
\hline & CAR1 & CAR2 & CAR3 & CAR4 & CAR5 & LR1 & LR2 & LR3 \\
\hline $\mathrm{C} 1$ & 0.00 & 0.04 & 0.10 & 0.00 & 0.00 & 0.00 & 0.08 & 0.20 \\
\hline $\mathrm{C} 2$ & 0.34 & 0.00 & 0.09 & 0.07 & 0.10 & 0.28 & 0.23 & 0.32 \\
\hline $\mathrm{C} 3$ & 0.74 & 0.06 & 0.00 & 0.17 & 0.03 & 1.00 & 1.00 & 1.00 \\
\hline $\mathrm{C} 4$ & 0.82 & 0.14 & 0.14 & 0.32 & 0.31 & 0.21 & 0.00 & 0.00 \\
\hline $\mathrm{C} 5$ & 0.90 & 0.17 & 0.05 & 0.40 & 0.32 & 0.40 & 0.49 & 0.48 \\
\hline \multirow[t]{2}{*}{ C6 } & 1.00 & 1.00 & 1.00 & 1.00 & 1.00 & 0.55 & 0.24 & 0.07 \\
\hline & OR1 & OR2 & OR3 & PR1 & PR2 & PR3 & PR4 & PR5 \\
\hline $\mathrm{C} 1$ & 0.23 & 0.00 & 0.42 & 0.00 & 0.00 & 0.01 & 0.00 & 0.00 \\
\hline $\mathrm{C} 2$ & 0.07 & 0.06 & 0.81 & 0.27 & 0.09 & 0.15 & 0.24 & 0.03 \\
\hline C3 & 0.93 & 0.25 & 0.00 & 0.39 & 0.13 & 0.26 & 0.38 & 0.05 \\
\hline $\mathrm{C} 4$ & 0.49 & 0.49 & 0.67 & 0.09 & 0.04 & 0.00 & 0.01 & 0.00 \\
\hline $\mathrm{C} 5$ & 1.00 & 0.85 & 0.05 & 0.06 & 0.13 & 0.25 & 0.39 & 0.06 \\
\hline C6 & 0.00 & 1.00 & 1.00 & 1.00 & 1.00 & 1.00 & 1.00 & 1.00 \\
\hline
\end{tabular}

Table 7 presents the grey relational coefficients that were calculated using Equation (10) by taking the distinguishing coefficient as 0.5 . This value of the distinguishing coefficient $(\zeta=0.5)$ offers moderate distinguishing effects and good stability (Chang \& Lin, 1999). In addition, the weights used in the analysis for each financial ratio are shown in Table 7.

Table 7. Grey relational coefficients and weights of the financial ratios

\begin{tabular}{ccccccccc}
\hline & CAR1 & CAR2 & CAR3 & CAR4 & CAR5 & LR1 & LR2 & LR3 \\
\hline Weights & 0.08 & 0.05 & 0.05 & 0.06 & 0.06 & 0.06 & 0.06 & 0.06 \\
C1 & 1.00 & 0.92 & 0.83 & 1.00 & 1.00 & 1.00 & 0.86 & 0.71 \\
C2 & 0.60 & 1.00 & 0.85 & 0.87 & 0.83 & 0.64 & 0.68 & 0.61 \\
C3 & 0.40 & 0.89 & 1.00 & 0.75 & 0.94 & 0.33 & 0.33 & 0.33 \\
C4 & 0.38 & 0.78 & 0.78 & 0.61 & 0.61 & 0.70 & 1.00 & 1.00 \\
C5 & 0.36 & 0.75 & 0.90 & 0.55 & 0.61 & 0.56 & 0.50 & 0.51 \\
C6 & 0.33 & 0.33 & 0.33 & 0.33 & 0.33 & 0.47 & 0.68 & 0.88 \\
\hline & OR1 & OR2 & OR3 & PR1 & PR2 & PR3 & PR4 & PR5 \\
\hline Weights & 0.06 & 0.06 & 0.07 & 0.08 & 0.07 & 0.06 & 0.06 & 0.07 \\
C1 & 0.69 & 1.00 & 0.54 & 1.00 & 1.00 & 0.98 & 1.00 & 1.00 \\
C2 & 0.87 & 0.89 & 0.38 & 0.65 & 0.85 & 0.77 & 0.67 & 0.94 \\
C3 & 0.35 & 0.67 & 1.00 & 0.56 & 0.79 & 0.66 & 0.57 & 0.91 \\
C4 & 0.50 & 0.51 & 0.43 & 0.85 & 0.93 & 1.00 & 0.98 & 1.00 \\
C5 & 0.33 & 0.37 & 0.90 & 0.90 & 0.80 & 0.66 & 0.56 & 0.89 \\
C6 & 1.00 & 0.33 & 0.33 & 0.33 & 0.33 & 0.33 & 0.33 & 0.33 \\
\hline
\end{tabular}

The weights used in the analysis for each financial ratio, as mentioned earlier, were determined based on the views of 15 senior managers (especially managers responsible for the financial affairs) working in the non-life insurance companies in Turkey.

In the final stage of the analysis, the grey relational grades should be calculated for the non-life insurance companies. The grey relational grade of each company was calculated by multiplying the grey relational coefficient by the weight of each financial ratio and by summing the result. After the calculation of these grades, the non-life insurance companies were ranked according to their grey relational grades. The grey relational grades for the companies and ranking are presented in Table 8.

Table 8. Grey relational grades for the non-life insurance companies and ranking

\begin{tabular}{ccc}
\hline Insurance Companies & Grey Relational Grade & Rank \\
\hline Aksigorta (C1) & 0.910 & 1 \\
Halk Sigorta (C4) & 0.748 & 2 \\
Anadolu Sigorta (C2) & 0.746 & 3 \\
Güneş Sigorta (C3) & 0.649 & 5 \\
Ray Sigorta (C5) & 0.636 & 6 \\
Unico Sigorta (C6) & 0.433 & 5 \\
\hline
\end{tabular}


As stated before, the higher grey relational grade shows better financial performance. For the 2010 to 2014 period, from the results of GRA based on the 5-year averages of each of 16 financial ratios, Aksigorta, which has the highest grey relational grade, took the first order among the 6 companies traded in BIST in terms of financial performance. Aksigorta was followed by Halk Sigorta and Anadolu Sigorta. In addition, it has been identified that the company with the lowest financial performance is Unico Sigorta, which has the lowest grey relational grade. These results that are related to the company ranking are congruent with the findings of Elitaş et al. (2012) and Kula et al. (2015). The results also show that profitability ratios have the greatest impact on the financial performance of non-life insurance companies traded in BIST. These results are in line with the findings obtained by Kung et al. (2006).

\section{Conclusions}

In this study, the financial performances of 6 non-life insurance companies traded in BIST as of the end of 2014 have been analyzed via the GRA method. Financial performances of non-life insurance companies in the 2010 to 2014 period have been examined in terms of the capital adequacy ratios, liquidity ratios, operating ratios, and profitability ratios. For the 2010 to 2014 period, the non-life insurance companies have been ranked according to the results of the GRA method in terms of financial performance. In addition, the results of the analysis showed that profitability ratios have the greatest impact on the financial performance of non-life insurance companies. It is possible to say that loss ratio and technical profitability ratio have been come to the fore between the profitability ratios.

Based on the results of the study, a non-life insurance company can provide sustainable profitable growth and come forward among its competitors with prudent underwriting strategies (more selective risk assessment), rational pricing policies, effective control of claims costs, and optimization of overheads.

When an overall assessment is done, it is expected that an insurance company improves its financial performance by

- having the appropriate amount of equity capital to its exposure to the risks (in particular to the underwriting risk),

- setting its investment policies to ensure the optimum combination of liquidity and profitability principles,

- determining a retention level convenient to the company's risk-taking capacity to establish a balance between insolvency risk and profitability,

- reducing the loss ratio by behaving more cautiously in risk selection and pricing according to risk, and

- following a growth strategy based on sustainable profitability.

\section{References}

Başpınar, A. (2005). Finansal Analiz Tekniklerinin Sigorta Şirketi Mali Tablolarına Uygulanması. Maliye Dergisi, (149), 5-35.

Brigham, E. F., \& Houston, J. F. (2001). Fundamentals of Financial Management (9th ed.). Orlando, FL: Harcourt College Publishers.

Chang, T. C., \& Lin, S. J. (1999). Grey Relation Analysis of Carbon Dioxide Emissions from Industrial Production and Energy Uses in Taiwan. Journal of Environmental Management, 56(4), 247-257. http://dx.doi.org/10.1006/jema.1999.0288

Chu, H. C., Hsu, Y. T., \& Lai, Y. H. (2008). A Weighted Routing Protocol Using Grey Relational Analysis for Wireless Ad Hoc Networks. Autonomic and Trusted Computing, Proceedings of 5th International Conference, ATC 2008, Oslo, Norway, June 23-25, 2008, pp. 655-663. http://dx.doi.org/10.1007/978-3-540-69295-9_52

Deng, J. L. (1982). Control problems of grey systems. Systems \& Control Letters, 1(5), 288-294. http://dx.doi.org/10.1016/S0167-6911(82)80025-X

Deng, J. L. (1989). Introduction to Grey System Theory. The Journal of Grey System, 1(1), 1-24.

Dorfman, M. S. (2005). Introduction to Risk Management and Insurance (8th ed.). Upper Saddle River, N.J.: Pearson Prentice Hall.

Elitaş, C., Eleren, A., Yıldız, F., \& Doğan, M. (2012). Grey Relation Analysis and Determination of Performance of Insurance Companies. Proceedings of 16. National Finance Symposium (pp. 521-530). Erzurum, Turkey, October 10-13, 2012. 
Feng, C. M., \& Wang, R. T. (2000). Performance evaluation for airlines including the consideration of financial $\begin{array}{llll}\text { ratios. Journal of Air Transport } & \text { Management, }\end{array}$ http://dx.doi.org/10.1016/S0969-6997(00)00003-X

Harrington, S. E., \& Niehaus, G. R. (2004). Risk Management and Insurance (2nd ed.). Boston: McGraw-Hill.

Huang, J. H., \& Peng, K. H. (2011). Using Rasch Model and GRA to Assess International Tourist Hotel Industry Performance. Journal of Grey System, 23(3), 299-310.

Kozak, S. (2011). Determinants of Profitability of Non-Life Insurance Companies in Poland during Integration with the European Financial System. Electronic Journal of Polish Agricultural Universities, 14(1).

Kula, V., Kandemir, T., \& Baykut, E. (2015). Borsa İstanbul Bünyesinde İşlem Gören Sigorta ve BES Şirketlerinin Finansal Performansının Gri İlişkisel Analiz Yöntemi ile İncelenmesi. Proceedings of 19. National Finance Symposium (pp. 217-233). Çorum, Turkey, October 21-24, 2015.

Kung, C. Y., \& Cheng, C. R. (2004). Grey Assessing the Performance of Enterprise Outsourcing Management. Journal of Grey System, 16(1), 63-72.

Kung, C. Y., \& Wen, K. L. (2007). Applying Grey Relational Analysis and Grey Decision-Making to evaluate the relationship between company attributes and its financial performance - A case study of venture capital $\begin{array}{lllll}\text { enterprises in Taiwan. Decision Support } & \text { Systems, } 43(3), 852 .\end{array}$ http://dx.doi.org/10.1016/j.dss.2006.12.012

Kung, C. Y., Yan, T. M., \& Chuang, S. C. (2006). GRA to Assess the Operating Performance of Non-Life Insurance Companies in Taiwan. Journal of Grey System, 18(2), 155-160.

Lin, C. T., \& Chang, H. F. (2010). Performance evaluation for medical industry in Taiwan: Applying Grey situation decision making. Journal of Grey System, 22(3), 219-226.

Liu, S., \& Lin, Y. (2006). Grey Information Theory and Practical Applications. Springer-Verlag London Limited.

Öner Kaya, E. (2015). The Effects of Firm-Specific Factors on the Profitability of Non-Life Insurance Companies in Turkey. International Journal of Financial Studies, 3(4), 510-529. http://dx.doi.org/10.3390/ijfs3040510

Özer, U. (2010). Kasko ve Trafik Sigortaları Kârlllık Değerlendirmesi. Reasürör, (76), 7-23.

Peker, İ., \& Baki, B. (2011). Performance Evaluation in Turkish Insurance Sector with Grey Relationship Analysis. International Journal of Economic and Administrative Studies, 4(7), 1-17.

Rejda, G. E., \& McNamara, M. J. (2014). Principles of Risk Management and Insurance (12th ed.). Boston: Pearson.

Republic of Turkey Prime Ministry the Undersecretariat of Treasury. (2014). Annual Report about Insurance and Individual Pension Activities - 2014. Ankara, Turkey.

Shiu, Y. (2004). Determinants of United Kingdom General Insurance Company Performance. British Actuarial Journal, 10(5), 1079-1110. http://dx.doi.org/10.1017/S1357321700002968

Swiss Reinsurance Company. (2011). World Insurance in 2010: Premiums back to growth - capital increases. Sigma, no. 2.

Swiss Reinsurance Company. (2012). World Insurance in 2011: Non-life ready for take-off. Sigma, no. 3.

Swiss Reinsurance Company. (2013). World insurance in 2012: Progressing on the long and winding road to recovery. Sigma, no. 3.

Swiss Reinsurance Company. (2014). World Insurance in 2013: Steering towards recovery. Sigma, no. 3.

Swiss Reinsurance Company. (2015). World insurance in 2014: Back to life. Sigma, no. 4.

Tiryaki, T. (2013). Hiyerarşik Faktör Modeliyle Hasar Ödeme Gücünün Tespiti. Proceedings of 1st National Insurance and Actuary Congress (pp. 227-237). Ankara, Turkey, June 6-7, 2013.

Tsai, H. Y., Huang, B. H., \& Wang, A. S. (2008). Combining AHP and GRA Model for Evaluation Property-Liability Insurance Companies to Rank. Journal of Grey System, 20(1), 65-78.

Wen, K. L. (2004). The Grey System Analysis and Its Application in Gas Breakdown and VAR Compensator Finding (Invited Paper). International Journal of Computational Cognition, 2(1), 21-44.

Wu, C. R., Lin, C. T., \& Tsai, P. H. (2010). Evaluating business performance of wealth management banks. 
European Journal of Operational Research, 207(2), 971- 979. http://dx.doi.org/10.1016/j.ejor.2010.04.034

Wu, H. H. (2002). A Comparative Study of Using Grey Relational Analysis in Multiple Attribute Decision Making Problems. Quality Engineering, 15(2), 209-217. http://dx.doi.org/10.1081/QEN-120015853

Wu, J. H., \& Chen, C. B. (1999). An Alternative Form for Grey Relational Grades. Journal of Grey System, 11(1), $7-12$.

Wu, W. Y., Hsiao, S. W., \& Tsai, C. H. (2008). Forecasting and Evaluating the Tourist Hotel Industry Performance in Taiwan Based on Grey Theory. Tourism and Hospitality Research, 8(2), 137-152. http://dx.doi.org/10.1057/thr.2008.17

Yan, T. M., \& Kung, C. Y. (2011). Business Performance Assessment of Insurance Company via Grey Relational Analysis. Journal of Grey System, 23(1), 83-90.

Zhai, L. Y., Khoo, L. P., \& Zhong, Z. W. (2009). Design concept evaluation in product development using rough sets and grey relation analysis. Expert Systems with Applications, 36(3), 7072-7079. http://dx.doi.org/10.1016/j.eswa.2008.08.068

\section{Note}

Note 1. Republic of Turkey Prime Ministry the Undersecretariat of Treasury; Regulation on Measurement and Assessment of Capital Requirements of Insurance and Reinsurance Companies and Pension Companies, The Official Gazette of the Turkish Republic, August 23, 2015 - 29454.

\section{Copyrights}

Copyright for this article is retained by the author(s), with first publication rights granted to the journal.

This is an open-access article distributed under the terms and conditions of the Creative Commons Attribution license (http://creativecommons.org/licenses/by/3.0/). 